\title{
Горизонти науки
}

UDC 911.3

\author{
Valeriy Rudenko, D.Sc. (Geography), Professor \\ e-mail: rudenko_valery@ukr.net \\ Vasyl Hryhorkiv, D.Sc. (Physics and Mathematics), Professor \\ e-mail:vasyl.hryhorkiv@gmail.com \\ Myroslav Zaiachuk, D.Sc. (Geography), Assosiate Professor \\ e-mail: zayachykmyroslav@ukr.net \\ Sviatoslav Ishchenko, PhD (Economy), Assistant \\ e-mail: isv.emm@gmail.com \\ Yuriy Fedkovych Chernivtsi National University, Ukraine
}

\section{SOCIAL-GEOGRAPHIC APPROACHES TO APPLICATION OF ECONOMIC-MATHEMATICAL MODELING IN PREDICTING THE PLACE OF UKRAINIAN FARMING ECONOMIES IN FOOD MARKET COMMODITIZATION}

\begin{abstract}
Social-geographic analysis of farmery with application of economic-mathematical modeling allowed for prediction of farming economies' role in food market commoditization. The equation of potential demand was suggested. Actual consumption and its recommended rates with respect to meat and meat products, milk and milk products, eggs, fish and fish products, bread and cereal products, potatoes, vegetables, fruits and berries, etc, were compared. Cartographic model of Ukrainian domestic food market's potential capacity (within good-money relations) was developed. The low level of purchasing power, especially in rural population, makes a high percentage of foodstuffs be beyond the goods-money relations. In rural areas, they (inclusive of farmers) produce and consume a significant portion of foodstuffs that escaped the goods-money relations, or such foodstuffs were given to them by the relatives. We regard that in the process of assessment of the capacity of domestic food market, this share of products should also be taken into account. The assessment also necessitates consideration of the number of urban and rural population in Ukrainian regions; manufacturing of certain types of agricultural production; needs in this or that type of product as prescribed by minimal and rational consumption rates. When predicting, with the use of economic-mathematical modeling, the places of farming economies in commoditization of food market, it is reasonable to apply the parameters of time series of the number of farming economies and the areas of lands used by them with consideration of the dynamics of population number and the level of its (population) self-provision with agricultural production. Application of predictive linear models shows that the share of production manufactured by farming economies will be most essential before 2020 on the market of potatoes and vegetables (reaching $15 \%$ ). Despite the predicted double increase in animal production, its share will stay to be insignificant (3-5\%).
\end{abstract}

Keywords: farming economies, economic-mathematical modeling, food market of Ukraine, equation of potential demand, prediction of farming economies' place in commoditization of food market.

Валерій Руденко, Василь Григорків, Мирослав Заячук, Святослав Іщенко. СУСПІЛЬНО-ГЕОГРАФІЧНІ ПІДХОДИ ЗАСТОСУВАННЯ ЕКОНОМІКО-МАТЕМАТИЧНОГО МОДЕЛЮВАННЯ ПРИ ПРОГНОЗУВАННІ МІСЦЯ ФЕРМЕРСЬКИХ ГОСПОДАРСТВ У НАПОВНЕННІ РИНКУ ПРОДОВОЛЬСТВА УКРАЇНИ

На основі суспільно-географічного аналізу розвитку фермерства за допомогою економіко-математичного моделювання здійснено прогнозування ролі фермерських господарств у наповненні ємностей ринку продовольства. Запропоновано рівняння потенційного попиту. Здійснено порівняння між фактичним споживанням та рекомендованою нормою споживання м'яса і м'ясопродуктів, молока і молокопродуктів, яєць, риби і рибопродуктів, хліба і хлібопродуктів, картоплі, овочів, плодів та ягід тощо. Укладено картографічну модель потенційної ємності внутрішнього продовольчого ринку України (в межах товарно-грошових відносин).

Ключові слова: фермерські господарства, економіко-математичне моделювання, ринок продовольства України, рівняння потенційного попиту, прогноз місця фермерських господарств у наповненні ринку продовольства.

Валерий Руденко, Василик Григоркив, Мирослав Заячук, Святослав Ищенко. ОБЩЕСТВЕННОГЕОГРАФИЧЕСКИЕ ПОДХОДЫ ПРИМЕНЕНИЯ ЭКОНОМИКО-МАТЕМАТИЧЕСКОГО МОДЕЛИРОВАННЯ ПРИ ПРОГНОЗИРОВАНИИ МЕСТА ФЕРМЕРСКИХ ХОЗЯЙСТВ В НАПОЛНЕНИИ ПРОДОВОЛЬСТВЕННОГО РЫНКА УКРАИНЫ

На основании общественно-географического анализа развития фермерства при помощи экономико-математического моделирования осуществленно прогнозирование роли фермерских хазяйств в наполнении ємкостей продовольственного рынка. Предложено уравнение потенциального спроса. Осуществлено сравнение между фактическим потреблением и рекомендуемимы нормами потребления мяса и мясопродуктов, молока и молокопродуктов, яиц, рыбы и рыбопродуктов, хлеба и хлебопродуктов, картошки, овощей, плодов и ягод. Составлено картографическую модель потенциальной емкости внутренного продовольственного рынка Уккраины ( в пределах товарно-денежных отношений).

Ключевые слова: фермерские хозяйства, экономико-математическая моделирование, продовольственный рынок Украины, уравнение потенциального спроса, прогноз места фермерских хозяйств в наполнении продовольственного рынка. 
Introduction. Formation of food market is a strategic task of the agrarian sector of national economy, and the state agrarian policy should thus choose the way of realization of economic reforms, predict the solution of multiple problems within the formation of market relations and consider both world experience and economic disposition of Ukraine. Major specificity of the formation of agrarian market relations lies in direct dependence of agricultural production upon market conditions, while the food market is the most socially vulnerable with its functioning, on the one hand, being directly connected with the social standard of living and purchasing power, and, on the other, with cost of production and pricing policy.

Commoditization of Ukrainian food market directly depends on the efficiency of functioning of agricultural product manufacturers, among which the role of farming economies is dynamically growing.

Goals. The present study aimed at socialgeographic analysis of Ukrainian food market formation, and, with the use of predictive decomposition models, at disclosure of farming economies' role in its (food market) commoditization.

Literature and Sources Review. Thorough analysis of Ukrainian market of agricultural production and food with respect to assessment of food market capacity and population's purchasing power is found in the works by P. Sabluk, O. Shpychak, Yu. Lutsenko, V. Zhuk, V. Boyko; specificities of functioning of sectoral and regional markets were disclosed in the works by G. Balabanov, Ya. Oliynyk, P. Sukhyy, etc.

Methods. The agrarian market bases on the market of agricultural products and food which is considered to be a system of forms of territorial concentration of interconnected agricultural sectors, food industry, food and public catering trade, and the market infrastructure. The problem of population's provision with food does not only depend on people's physiological needs, but also on the level of their purchasing power. That is, the foodstuffs needs shall be solely realized if the population has sufficient money to buy them. In its totality, it forms the so called capacity of the market.

The normative capacity of domestic food market is defined as a sum of products of the consumption rate of certain (nth) type of food, the average customer price of this type of food, and the average annual number of resident population:

$$
\mathrm{FMC}=\sum_{n=1}^{c} \quad(\mathrm{CRn} * \mathrm{CPn}) * \mathrm{H}
$$

where FMC is the capacity of domestic food market, UAH;

$\mathrm{CR} n$ - consumption rate of the nth type of food per individual, $\mathrm{kg}$;

$\mathrm{CP} n$ - customer price of the nth type of food, UAH;

$\mathrm{H}$ - average annual number of legal population, people;

$\mathrm{n}$ - type of food resources that form the capacity of domestic food market;

$\mathrm{c}$ - number of types of food resources that form the capacity of domestic food market [4, p.27].

Optimization of geospatial and sectoral structures of farming mode does not only presuppose determination of general trends of its development and allocation of single economies or their combinations to help provide for rational needs of regional population in major types of agricultural products, but also the products' manufacturing in a volume that exceeds domestic needs. This is precisely why the prediction of the role of farming economies in commoditization of food market is an essentially up-to-date task.

To predict the share of farming economies in the market of food we suggest the equality of potential demand as follows:

$$
Y_{i}=\left(\left(1-k_{M}\right) \cdot P_{M}+\left(1-k_{c}\right) \cdot P_{c}\right) \cdot N_{j}, i=\overline{1,5}, j=\min , r \text {, }
$$

where $Y_{i}$ is potential needs in $i$-type of agricultural product;

$k_{M}, k_{c}$ stand for coefficients of urban and rural population's self-supportability with agricultural products; tion;

$P_{M}, P_{c}$ are the numbers of urban and rural popula-

$N_{j}, j=\min , r$ is the consumption rate for corresponding type of agricultural product per 1 individual as provided by minimal and rational standards.

Thus, the potential demand is understood as the volume of this or that type of agricultural product under goods-money relations with consideration of the prescribed level of provision with minimal and rational standards of consumption. That is, it is a certain quantity of agricultural production which would be purchased by population of a certain region.

Results. The market of agricultural production and its derived products is formed by the subjects of market relations represented by private enterprises of family type, inclusive of farming economies, collective enterprises and those within the system of procurement, storage, processing and realization.

Calculations that proceed from rational and minimal standards of consumption of major foodstuffs that form the consumer goods basket seems to be the most adapted method to assess the food market capacity. Annual consumption rates per individual and the total number of population serve to be the basis for such calculations. The values of the major foodstuffs annual consumption rates allow for comparisons between the recommended consumption rates and the major foodstuffs' actual consumption.

Traditionally in Ukraine, the actual consumption of bread, cereal products and potatoes exceeds the recommended consumption rates. On the contrary, the actual consumption of milk and milk products, meat and meat products, fruits and berries, vegetables and gourds is significantly lower than it is recommended by the standards ( Table 1). Analyzing the dynamics of consumption, we can not but note the decrease in consumption per individual of milk and milk products, fruits and berries, as well as some increase in consumption of eggs, fish and fish products, vegetables and gourds. 
Foodstuffs' actual consumption and its recommended rates [4]

\begin{tabular}{|c|c|c|c|c|c|c|c|c|c|c|c|c|c|}
\hline \multirow[t]{2}{*}{$\begin{array}{c}\text { Major } \\
\text { products }\end{array}$} & \multirow{2}{*}{ 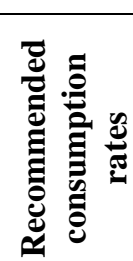 } & \multicolumn{6}{|c|}{$\begin{array}{l}\text { Actual consumption of major food- } \\
\text { stuffs, kg/individual }\end{array}$} & \multicolumn{6}{|c|}{$\begin{array}{c}\begin{array}{c}\text { Difference between actual consumption } \\
\text { and recommended consumption rate, } \\
\text { kg/individual }\end{array} \\
\end{array}$} \\
\hline & & ஓ & $\stackrel{2}{2}$ & \&్ & ڤి & $\stackrel{\circ}{\stackrel{2}{c}}$ & $\stackrel{m}{2}$ & $\stackrel{2}{2}$ & $\stackrel{2}{2}$ & \&્ণ & ஜे & $\stackrel{\circ}{\circ}$ & $\stackrel{m}{\stackrel{n}{2}}$ \\
\hline $\begin{array}{l}\text { Meat and } \\
\text { meat } \\
\text { products }\end{array}$ & 83 & 68 & 39 & 33 & 39 & 52 & 56,1 & -15 & -44 & -50 & -44 & -31 & $-32,9$ \\
\hline $\begin{array}{l}\text { Milk and } \\
\text { milk } \\
\text { products }\end{array}$ & 380 & 373 & 245 & 199 & 226 & 205 & 220,9 & $\begin{array}{l}-7 \\
\end{array}$ & -135 & -181 & -154 & -175 & $-159,1$ \\
\hline Eggs, pieces & 290 & 272 & 171 & 166 & 238 & 290 & 309 & -18 & -119 & -124 & -52 & 0 & +19 \\
\hline $\begin{array}{l}\text { Fish and fish } \\
\text { products }\end{array}$ & 20 & 18 & 4 & 8 & 14 & 37 & 14,6 & -2 & -16 & -12 & -6 & +17 & $-5,4$ \\
\hline $\begin{array}{l}\text { Bread and } \\
\text { cereal } \\
\text { products }\end{array}$ & 101 & 141 & 124 & 125 & 124 & 111 & 108,4 & +40 & +23 & +24 & +23 & +10 & $+6,6$ \\
\hline Potatoes & 124 & 131 & 124 & 135 & 136 & 129 & 135,4 & +7 & 0 & +11 & +12 & +5 & $+11,4$ \\
\hline $\begin{array}{l}\text { Vegetables } \\
\text { and gourds }\end{array}$ & 161 & 103 & 97 & 102 & 120 & 144 & 63,3 & -58 & -64 & -59 & -41 & -17 & $+2,3$ \\
\hline $\begin{array}{c}\text { Fruits and } \\
\text { berries }\end{array}$ & 90 & 47 & 33 & 29 & 37 & 14 & 56,3 & -43 & -57 & -61 & -53 & -76 & $-33,7$ \\
\hline Sugar & 38 & 50 & 32 & 37 & 38 & 37 & 37,1 & +12 & -6 & -1 & 0 & +1 & $-0,9$ \\
\hline
\end{tabular}

According to consumer goods basket, the minimal consumption rates per individual are as follows: potatoes - $99 \mathrm{~kg}$, vegetables - $105 \mathrm{~kg}$, fruits - $66 \mathrm{~kg}$, milk and milk products $-331 \mathrm{~kg}$, meat, all sorts $-50,3 \mathrm{~kg}$ (beef 20,0 ; pork $-14,1 \mathrm{~kg}$, and poultry meat $-14,9 \mathrm{~kg}$ ), eggs 223,6 pieces; fish and fish products $-12 \mathrm{~kg}$. These values are less than the rational consumption rates where meat and meat products should amount to $83 \mathrm{~kg}$, milk and milk products $-380 \mathrm{~kg}$, eggs -290 pieces, fish and fish products $-20 \mathrm{~kg}$, bread and cereal products -101 $\mathrm{kg}$, potatoes $-124 \mathrm{~kg}$, vegetables and gourds $-161 \mathrm{~kg}$, fruits and berries $-90 \mathrm{~kg}$ [ 4 ].

The minimum subsistence level in 2013 was UAH1176,00 (UAH1032,00 - children before 6; UAH1286,00 - children between 6 and 18, UAH1218,00 - employable people, UAH949,00 - disabled people). The share of Ukrainian population's food requirement expenses still stay at a level of $50-56 \%$ out of the family budget (see Table 2).

Consumer goods basket (foodstuffs) [2, 4, 5]

Table 2

\begin{tabular}{|c|c|c|c|c|c|c|}
\hline \multirow{2}{*}{ Parameter } & \multicolumn{2}{|c|}{$\mathbf{2 0 0 5}$} & \multicolumn{2}{|c|}{$\mathbf{2 0 1 0}$} & \multicolumn{2}{c|}{$\mathbf{2 0 1 3}$} \\
\cline { 2 - 7 } & $\begin{array}{c}\text { UAH/ } \\
\text { individual }\end{array}$ & Structure, \% & $\begin{array}{c}\text { UAH/ } \\
\text { individual }\end{array}$ & Structure, \% & $\begin{array}{c}\text { UAH/ } \\
\text { individual }\end{array}$ & Structure, $\%$ \\
\hline Meat and meat products & 639,9 & 24,6 & 1534,4 & 23,0 & 1538,1 & 21,0 \\
\hline Milk and milk products & 298,6 & 11,5 & 887,8 & 13,3 & 974,1 & 13,3 \\
\hline Eggs & 92,7 & 3,6 & 213,9 & 3,2 & 293,0 & 4,0 \\
\hline Fish and fish products & 146,9 & 5,7 & 292,7 & 4,4 & 329,6 & 4,5 \\
\hline $\begin{array}{c}\text { Bread and cereal } \\
\text { products }\end{array}$ & 415,2 & 16,0 & 969,8 & 14,5 & 1098,6 & 15,0 \\
\hline Potatoes & 190,2 & 7,3 & 567,6 & 8,5 & 607,9 & 8,3 \\
\hline Vegetables and gourds & 356,6 & 13,7 & 977,3 & 14,6 & 1084,0 & 14,8 \\
\hline Fruits, berries, grape & 135,4 & 5,2 & 454,7 & 6,8 & 505,4 & 6,9 \\
\hline Sugar, confectionery & 244,9 & 9,4 & 626,4 & 9,4 & 688,5 & 9,4 \\
\hline Vegetable oil & 77,7 & 3,0 & 159,5 & 2,4 & 205,1 & 3,8 \\
\hline $\begin{array}{c}\text { Product's share } \\
\text { in the aggregate cost, } \%\end{array}$ & 56,6 & - & 51,4 & - & 53,5 & - \\
\hline $\begin{array}{c}\text { Yearly total } \\
\text { per individual }\end{array}$ & 2598 & 100 & 6684 & 100 & 7324 & 100 \\
\hline
\end{tabular}


It should be noted that such share should not exceed $1 / 3$ of the minimum subsistence level, and it is needless to say that it is under $15 \%$ in advanced countries. The majority of the expenses fall to purchase of meat and meat products, potatoes, bread and cereal products, milk and milk products. It is widely acknowledged that the population's low purchasing power preconditions high risks of domestic market's exposure to fluctuations in foodstuff prices, which predetermines the elasticity of links between the needs and agricultural product prices.

The low level of purchasing power, especially in rural population, makes a high percentage of foodstuffs be beyond the goods-money relations. In rural areas, they (inclusive of farmers) produce and consume a significant portion of foodstuffs that escaped the goods-money relations, or such foodstuffs were given to them by the relatives. It is especially the matter with eggs $-70 \%$, potatoes -84 , vegetables -49 , milk -41 , meat $-34,5$, fruits and berries $-33,7 \%$. We regard that in the process of assessment of the capacity of domestic food market, this share of products should also be taken into account. On the average, such segment of food consumption is within $4 \%$ in urban population and $35 \%$ in rural (Table 3 ). The assessment also necessitates consideration of the number of urban and rural population in Ukrainian regions; manufacturing of certain types of agricultural production; needs in this or that type of product as prescribed by minimal and rational consumption rates.

Table 3

The share of foodstuffs that stay beyond the goods-money relations (\%) [4]

\begin{tabular}{|c|c|c|}
\hline & Urban households & Rural households \\
\hline Bread and cereal products & 0,0 & 1,8 \\
\hline Fish and fish products & 0,4 & 1,5 \\
\hline Eggs & 5,3 & 70,4 \\
\hline Vegetable oil & 0,0 & 0,2 \\
\hline Sugar & 1,7 & 5,6 \\
\hline Meat and meat products & 2,2 & 34,5 \\
\hline Milk and milk products & 1,4 & 41,2 \\
\hline Fruits, berries, nuts, grape & 5,3 & 33,7 \\
\hline Potatoes & 17,2 & 83,7 \\
\hline Vegetables and gourds & 9,2 & 49,2 \\
\hline
\end{tabular}

Production of bread and cereal products in Ukraine completely covers the population's needs within both minimal and rational consumption standards. The volumes of cereal cropping in the majority of Ukrainian regions are sufficient for even surplus production of bread and cereal products, save for Zakarpattia, IvanoFrankivsk, Chernivtsi administrative regions and the City of Kyiv. Consumption of potatoes stays to a great extent beyond the goods-money relations. With consideration of minimal consumption rates and as prescribed by the standards of the consumer goods basket, regional production of potatoes is to some extent insufficient in highly urbanized Donetsk and Dnipropetrovsk administrative regions. On condition that rational consumption rates are provided, said regions shall be added with the Zaporizhzhia, Lugansk and Kharkiv administrative regions. On the whole, the capacity of domestic gourds market covers the population's minimal and rational needs, save for highly urbanized regions where the volumes of production do not provide even for the minimal standards of consumer goods basket. It is especially the matter with the City of Kyiv and the Kyiv, Donetsk and Lugansk regions. If rational standards of consumption are regarded, the situation with the provision of vegetables and gourds within the domestic market also stays to be unsatisfactory in Dinpropetrovsk, Zaporizhzhia, Ivano-Frankivsk, Sumy and Kharkiv administrative regions. Much more complicated is the situation in the domestic market of animal products (map 1).

The difference between the production of milk and milk products and their minimal need amounts to 6286,1 thousand tons, rational standard - 8214,9 thousand tons. The minimal standard of consumer goods basket is provided by the goods' domestic production only in the Vinnytsia, Volyn, Poltava, Khmelnytskyy and Chernigiv administrative regions. Though the capacity of the market of milk is significant, there exist multiple problems with cattle breeding. The capacity of meat market is unfilled, too. At the same time, the effect of population's purchasing power is the most sensitive on this market, and high prices often make people substitute the meat for the other products. The difference between the actual production of meat and its minimal standards of consumption in Ukraine makes 739,1 thousand tons and is represented by a minus quantity in all regions save for the Volyn Region ( $+17,6$ thousand tons) and the Autonomous Republic of Crimea ( $+6,2$ thousand tons). As to rational standards of consumption, the difference makes 2049,3 thousand tons and is represented by a minus quantity in all Ukrainian regions. The meat markets of the Donetsk region, the City of Kyiv and the Kyiv Region, as well as those of Kharkiv, Odesa, Lugandsk, Lviv, Dnipropetrovsk and Zaporizhia regions are the most unfilled internal markets. The market of eggs is rather balanced since their actual production exceeds minimal standards and lies within the levels of provision of rational standards of consumption. The minimal consumption rates are provided by the internal regional production in all Ukrainian regions, while there is a slight gap with respect to rational standards in the Lviv, Dnipropetrovsk, Volyn, Cumy and Chernigiv regions [2]. 


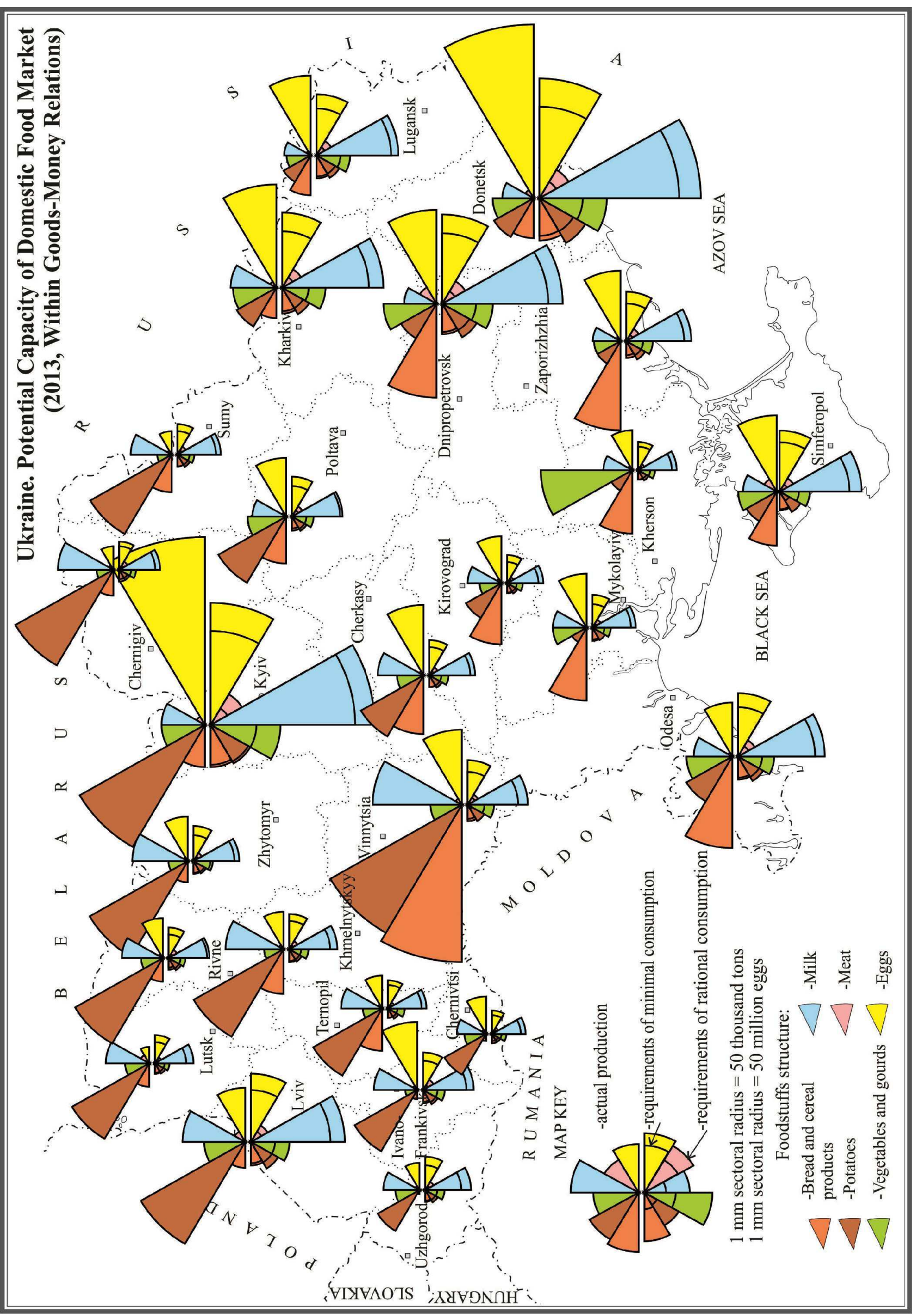

Map 1. Potential capacity of domestic food market (within goods-money relations) 
Their most important role is played by farming economies in commoditization of the market of potatoes where they give $10 \%$ with respect to minimal consumption rates and 7,9\% - rational. In some regions, the farmers' croppage sufficiently provides for both nominal and rational standards (with consideration of goods-money relations), as it is the case in the Ternopil Region (167,3\% and $140 \%$ correspondingly). The farmers' commoditization of regional market of potatoes dominates in the Khmelnytskyy Region $(81,7 \%$ and 63,9\%), and Chernivtsi Region (50\% and 40,4\%), while it forms the $1 / 3$ of the market in the Zhytomyr Region, and is of weighty share (over 10\%) in the Volyn, Zakarpattia and Kherson regions. In 2013, the farmers filled $8,2 \%$ of the minimal consumption rates in the market of vegetables, and $5,3 \%$ of the rational standards. With that, the farming economies of the Kherson Region produce nearly $135 \%$ of regional needs according to minimal consumption rates and $90,9 \%$ with respect to rational standards. Substantial is also the role of the Mykolayiv Region where they cover $24,5 \%$ and $16,3 \%$ correspondingly.

Much more less is the share of farming economies in filling the markets with meat production. Farmers commoditize the meat market of Ukraine to the amount of only $2,8 \%$ of minimal and $1,9 \%$ - rational standards of consumption. It is in the Lviv (31,9\% and 18,7\%), Rivne (7,1\% and 4,5\%), and Khmelnytskyy (6,5\% and 3,8\%) administrative regions where the farmers commoditize meat markets most largely. The market of milk is commoditized by farming economies to the amounts of $1,2 \%$ and $1 \%$ correspondingly (over $5 \%$ in the Chernigiv and Khmelnytskyy regions); market of eggs $-0,7 \%$ and $0,5 \%$ (farming economies in Lviv and Zhytomyr regions take the lead with over $5 \%$ ).

The trends in the development of farmery in Ukraine, and the potential demand for some types of agricultural production served to be the basis for predictive calculations of the share of farming economies in commoditization of Ukrainian market of food.

Having applied the predictive trend equations of decomposition models (2) that follow levelling of time series of quantity of farming economies, areas of lands used by them, and the potential demand, we have predicted the share of farming economies that would commoditize the food market with certain types of their production (Table 4).

$$
\begin{aligned}
& Y_{1}^{\min }=106,4848042-0,0022286 X_{1}+0,0000063 X_{2}-0,0000106 X_{3}, \\
& Y_{2}^{\text {min }}=-222,4386689+0,000633 X_{1}+0,0000069 X_{2}+0,0000466 X_{3}, \\
& Y_{3}^{\text {min }}=3,1845208-0,0006546 X_{1}+0,0000026 X_{2}+0,000008 X_{3}, \\
& Y_{4}^{\text {min }}=-0,2478273-0,0000952 X_{1}+0,0000005 X_{2}+0,0000002 X_{3}, \\
& Y_{5}{ }^{\min }=-10,0675903-0,0000609 X_{1}+0,0000006 X_{2}+0,0000014 X_{3}, \\
& Y_{1}^{r}=114,0088218-0,0018183 X_{1}+0,0000043 X_{2}-0,0000137 X_{3}, \\
& Y_{2}^{r}=70,4063238-0,0020384 X_{1}+0,0000056 X_{2}-0,0000006 X_{3}, \\
& Y_{3}^{r}=13,9659810-0,000493 X_{1}+0,0000016 X_{2}+0,0000006 X_{3}, \\
& Y_{4}^{r}=-1,9630272-0,0000510 X_{1}+0,0000004 X_{2}+0,0000002 X_{3}, \\
& Y_{5}^{r}=-6,3175420-0,0000246 X_{1}+0,0000004 X_{2}+0,0000006 X_{3},
\end{aligned}
$$

\begin{tabular}{|c|c|c|c|c|c|c|c|c|c|c|}
\hline & \multicolumn{2}{|c|}{ Potatoes } & \multicolumn{2}{|c|}{ Vegetables } & \multicolumn{2}{|c|}{ Meat } & \multicolumn{2}{|c|}{ Milk } & \multicolumn{2}{|c|}{ Eggs } \\
\hline & 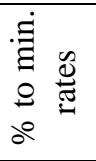 & 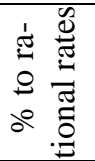 & 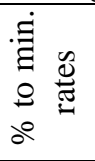 & 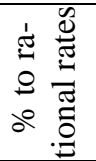 & 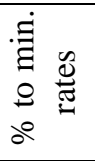 & 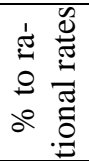 & 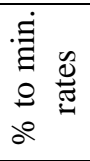 & 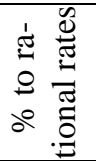 & 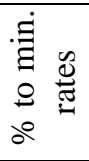 & 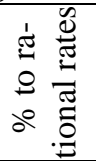 \\
\hline 1995 & 0,8 & 0,7 & 0,7 & 0,1 & 0,4 & 0,2 & 0,4 & 0,3 & 0,2 & 0,18 \\
\hline 2000 & 2,8 & 2,6 & 2,5 & 0,3 & 0,6 & 0,4 & 0,6 & 0,5 & 0,2 & 0,2 \\
\hline 2005 & 4,3 & 3,4 & 8,4 & 0,6 & 1,2 & 0,7 & 0,9 & 0,8 & 0,5 & 0,4 \\
\hline 2010 & 5,7 & 4,6 & 5,7 & 3,7 & 2,1 & 1,4 & 0,9 & 0,7 & 1,3 & 1,0 \\
\hline 2013 & 9,9 & 7,9 & 8,2 & 5,3 & 2,8 & 1,9 & 1,2 & 1,0 & 0,7 & 0,5 \\
\hline \multicolumn{11}{|c|}{ Prediction } \\
\hline 2017 & 11,7 & 9,3 & 12,1 & 5,6 & 3,2 & 2,2 & 1,3 & 1,2 & 0,9 & 0,6 \\
\hline 2020 & 14,5 & 11,5 & 14,5 & 7,1 & 4,0 & 2,7 & 1,8 & 1,5 & 1,0 & 0,7 \\
\hline
\end{tabular}

where $Y_{i}^{j}, i=\overline{1,5}, j=\min , r$ _ share of farmers supplying the market with $i$-product according to minimal or rational consumption rates;

$$
\begin{aligned}
& X_{1} \text { - number of farmers; } \\
& X_{2} \text { - land areas owned by farmers; } \\
& X_{3} \text { - potential demand for corresponding type of agricultural production. }
\end{aligned}
$$

Table 4

The share of farming economies commoditizing the Ukrainian food market, \% (within the goods-money relations) 
Discussion. Suggested prediction is optimistic since it takes into account the trends of increasing number of farming economies as well as the increasing areas of lands used by them. Firstly, said trends may change with time; secondly, there exists a number of external factors that may significantly affect the place of farming economies in commoditization of food market.

Conclusions. 1. When predicting, with the use of economic-mathematical modeling, the places of farming economies in commoditization of food market, it is reasonable to apply the parameters of time series of the number of farming economies and the areas of lands used by them with consideration of the dynamics of population number and the level of its (population) selfprovision with agricultural production.

2. Application of predictive linear models shows that the share of production manufactured by farming economies will be most essential before 2020 on the market of potatoes and vegetables (reaching $15 \%$ ). Despite the predicted double increase in animal production, its share will stay to be insignificant (3-5\%).

3. Efforts, inclusive of those by the state, should be directed towards stimulation of development in farming economies of this or that line of production activity (depending upon regional specificities of food market formation).

\section{Список використаних джерел:}

1. Григорків В.С. Моделювання економічної динаміки з урахуванням ринку сільськогосподарського призначення / В.С. Григорків, Л.М. Буяк, С.В. Іщенко - Чернівці: ЧНУ, 2015. - 264 с.

2. Заячук М.Д. Геопросторова організація фермерського укладу України: [монографія] / М.Д. Заячук. Чернівці: Букрек, 2015. - 520 с.

3. Zaiachuk M. Geogratial particularities of farming formation in Ukraine / M. Zaiachuk // Geographia Technica. 2013. - № 2. - P. 80-88.

4. Смність внутрішнього споживного ринку сільськогосподарської продукції та продовольства: монографія / [Шпичак О.М., Лупенко Ю.О., Жук В.М. та ін.]; за ред. О.М. Шпичака. - К.: ННЦ ІАЕ, 2013. - 186 с.

5. Статистичний збірник «Сільське господарство України за 2013 рік» / Державна служба статистики ; за ред. Н.С. Власенко. - К.: ДП «Інформаційно-аналітичне агентство», 2014. - 386 с.

\section{References:}

1. Hryhorkiv, V.S., Buiak, L.M., Ishchenko, S.V. (2015). Modelyuvannya ekonomichnoi dynamiky z urakhuvannyam rynku silskohospodarskoho pryznachennya [Modeling of Economic Dynamics with Consideration of Agricultural Market]. Chernivtsi: ChNU, 264.

2. Zaiachuk, M.D. (2015). Geoprostorova organizatsiya fermerskoho ukladu Ukrainy [Geospatial Organization of Farming Mode in Ukraine]. Chernivtsi: Bukrek, 520.

3. Zayachuk, M. (2013). Geogratial particularities of farming formation in Ukraine. Geographia Technica, 2, 80-88.

4. Shpychak, O.M., Lupenko, Yu.O., Zhuk, V.M. (2013). Yemnist vnutrishnoho spozhyvnoho rynku silskohospodarskoi produktsii ta prodovolstva. K.: NNTs IAE, 186.

5. Statystychnyi zbirnyk „Silske hospodarstvo Ukrainy za 2013 rik” (2014) [“2013 Ukrainian Agriculture”, a Statistical Collection]. Derzhavna sluzhba statystyky; za red. N.S. Vlasenko. K.: DP „Informatsiino-analitychne agentstvo", 386. 